\title{
Place-based disruptions of humanism, coloniality and anti-blackness in early childhood education
}

\author{
Fikile Nxumalo \\ Department of Curriculum, Teaching \& Learning, OISE, University of Toronto \\ Corresponding Author: f.nxumalo@utoronto.ca
}

(Submitted: 6 April 2020; Accepted: 4 August 2020)

\begin{abstract}
This essay engages with the generative potentials and necessity of attunement to place in education. I focus in particular on what bringing Indigenous and Black feminisms and feminist new materialisms into conversation might mobilize towards unsettling the anthropocentric, colonial, and anti-Black inheritances of early childhood education. I situate my engagements with place within ongoing and intensifying anthropogenic environmental precarity that underline the imperative of more relational ways of living and learning in always already more-than-human worlds. In bringing feminist new materialisms into conversation with Indigenous and Black feminisms, I am interested in mobilizing relationalities that unsettle human centeredness while also disrupting the universalization of the category of the human.
\end{abstract}

Keywords: affective pedagogy, Black feminism, environmental education, indigenous feminism

\section{Situating orientations}

In this essay, I discuss some practices and concepts that I have found generative in engaging with the implications of pedagogically attending to environmental precarity. My particular concerns are the consequences for teaching and learning with young children amidst climate change, ongoing coloniality, extractive racial capitalism, and their interconnections - all of which continue to create highly asymmetrically distributed unlivability for both human and more than human life. I want to begin though by situating my work. Firstly, I draw inspiration from feminist scholars including Bagele Chilisa (2019), Patricia Hill Collins (1989, 2008), and Donna Haraway (2003), who all emphasize the importance of partial, implicated, and situated perspectives. This means that it is important to note that I locate my work in settler colonial geopolitical contexts in the United States and Canada where I am in multiple and shifting relations with early childhood places, educators, and children. Put another way, non-innocent epistemologies and 'ontologies of connectedness and relatedness' 
(Chilisa, et al., 2017: 333) are central orientations to my work. For instance, I am situated within emergent and already-present relations shaped by gender, coloniality, immigrant status, and racialized marginalization in these places. At the same time, my work is also shaped by a privileged perspective as a researcher and pedagogista ${ }^{1}$ within early learning places and spaces. Situating the orientations of this work also includes attuning to the ways in which place itself matters in particular (not generalized) ways and is an active and agentic participant in pedagogical encounters (Nxumalo, 2019a; Tuck, et al., 2015). These attunements are threaded through this paper. At this point, I want to note that attending to the specificity of place means that the work I will share here has limited portability across different socio-cultural and more-than-human geographies. Despite this, my hope is that there are resonances for other situated 'doings' of research and pedagogy that also seek to respond to the emplaced entanglements of anti-Blackness, settler colonialism, and environmental precarity in educational contexts. For the remainder of the paper, drawing from examples in my research, I discuss possibilities for early childhood education to confront anti-Blackness, settler colonialism, and environmental precarity, and their interconnections.

\section{Why connect anti-Blackness, settler colonialism, and environmental precarity?}

I am interested in possibilities for early childhood education in settler colonial North American contexts, to shift towards relating to place, including its human and more-than-human inhabitants, in ways that are simultaneously anti-colonial, anti-racist and attentive to the intrinsic relationality between human and more-than human life. I see these as necessary onto-epistemological shifts (Barad, 2007; Pérez and Saavedra, 2017) for early childhood education to grapple with the implications of learning and living within past, present, and impending (re)ending of worlds, as precipitated by climate catastrophe (Davis and Todd, 2017; Stein, 2019). In responding to climate catastrophe in early learning places, why bring anti-colonial, anti-racist and more-than-human relational practices together? Firstly, there is a need for attention to be paid to the ways in which environmental precarity, anti-Blackness, and settler colonialism are interconnected and how they come to matter within educational contexts (Davis and Todd, 2017; Tuck, et al., 2014). In this regard, engagements with the implications of living in current times of environmental damage in what is now North America require noticing and responding to the interconnections of the slavery, settler colonialism and extractivist ways of relating to the more than human world are interconnected (Davis

\footnotetext{
${ }^{1}$ The role of the pedagogista in North American early childhood settings has been inspired by Reggio Emilia preschools in Italy, where this role is an important figure. Generally speaking, the pedagogista works in collaboration with educators, children, families and other human and more-than-human participants in educational protagonist approach to extend thinking and engagements with specific learning inquiries, including their inter-relationships with philosophical, socio-political and ethical underpinnings of the early childhood classroom (Nxumalo, et al., 2018; Vintimilla, 2016).
} 
and Todd, 2017; King, 2019; Vergès, 2017). As work in Black Studies has demonstrated, the violences of slavery persist in its afterlife through anti-Blackness, in education and beyond including racial capitalist conditions of asymmetrically distributed precarity (Dumas and ross, 2016; Hartman, 2007; Nxumalo, 2019b; Sharpe, 2016).

The interrelationships between settler colonialism, capitalist extraction, and anti-Blackness are of significance in rethinking educational priorities for learners and educators of all ages living in North America in current times. However, the implication of these inter-relationships has not been taken up significantly in North American early childhood environmental education, which remains dominated by romantic, humanist and developmental approaches to understanding child-nature relationships, including discourses of bringing children 'closer to nature' (Nelson, et al., 2018; Nxumalo, 2019a; Taylor, 2017).

In seeking alternatives to these humanist, apolitical discourses and their materialized enactments in everyday place-based pedagogical encounters, I have turned to Black and Indigenous feminisms, and feminist new materialisms. These perspectives have and continue to help me to sharply attend to the issues that I am interested in disrupting in my work. Bringing these perspectives into conversation does not imply that individually they do not attend to one or more of the issues of inheritances of settler colonialism, anti-Blackness, and capitalist extraction. There are also tensions in bringing them together as seen for instance in Black and Indigenous feminist analyses of the ways in which feminist new materialist disruptions of humanism can universalize Euro-Western epistemologies of the human and, leave unexamined ongoing material, embodied and discursive dehumanization enacted through anti-Blackness and settler colonialism (Jackson, 2015; King, 2017; Nxumalo and Cedillo, 2017; Todd, 2016; Tuck, 2014).

In my research I have brought these perspectives together in inquiring how the places that I encounter with children and educators can be affectively experienced in ways that foreground historically marginalized people, lands and waters including being-with places in ways that recognize them as inherently pedagogical (Simpson, 2014). A key part of these pedagogical place encounters is bringing to children human and more-than-human place stories in ways that underline Indigenous presence and disrupt colonial erasure (Nxumalo, 2019c; Simpson, 2014). These modes of presencing include nurturing affective and reciprocal attention to the vibrant more-than-human relationalities of place. A second ethos that underpins my critical encounters with place is to seek possibilities for disrupting deficit constructions of Black relations to so called natural places (Nxumalo, 2018; Nxumalo and Cedillo, 2017; Nxumalo and ross, 2019).

Threaded through all of these commitments is an interest in bringing forward possibilities for (re)storying what is considered present in the pedagogical encounters I work with. A question that threads through my work then is: What might attention to Indigenous relational presences, to ongoing colonialisms and anti-Blackness, and to more-than-human entanglements in everyday 
pedagogical encounters with 'natural' places in particular settler colonial contexts do toward enacting decolonial possibilities (Nxumalo, 2019a)?

\section{Disrupting anti-Blackness in environmental education}

Black feminist scholar Christina Sharpe's book In the Wake: On Blackness and Being provides powerful insights into the ways in which '...the weather is the total climate; and that climate is antiBlack' (2016: 104). One such insight is through her storying of an encounter with a photograph of a young Black girl, a survivor of the 2010 Haiti earthquake, with a piece of tape reading 'Ship' affixed to her forehead. I read this encounter as an important lesson for thinking through and making visible the appearances of banal anti-Blackness of environmental education in North American contexts. The girl in the photograph is marked as a subject of care and protection; yet, this subjection as materialized by the sticker on the forehead is also dehumanizing (Sharpe, 2016). Similarly, discourses of care that are ascribed to connecting Black children and youth to nature, particularly those deemed 'at-risk' can be dehumanizing. This banal anti-Blackness emerges in several ways including through the deficit framing of children for whom nature is constructed as an individual 'fix' without considerations of underlying systemic conditions that cause for instance a lack of access to 'green' spaces and food gardens (Cairns, 2017). Not only do these constructions of nature perpetuate human-centered views of nature, they also rely on privileged, purist and humanist constructions of what counts as nature (Nxumalo and ross, 2019; Taylor, 2017). As one of several modes of resistance to these anti-Black formations in early childhood education, I have turned to Black feminist theories of testifying and witnessing (Collins, 1998; Tarpley, 1995). What I call testifying-witnessing refers to concepts and practices that make anti-Blackness in environmental education visible and at the same foreground stories that highlight the ways in which Black children's geographies affirm Black life and place relations (McKittrick, 2013; Nxumalo, 2018). Importantly these relations are an escape from colonial humanist logics of Black subjectivities (King, 2019). Testifying-witnessing can materialize in multiple ways that include (re)storying place relations in ways that center Black belonging, Black futurities, and Black children's modes of relating to the more-than-human world. For example, my dear colleague and friend kihana ross and I (2019) have drawn inspiration from Octavia Butler's $(1995,1998)$ work to experiment with Black speculative fiction as a mode of testifying-witnessing that interrupts the anti-Blackness of early childhood environmental education in North America. In this work, we enact speculative storytelling methods that refuse the assumed dislocation of Black childhoods from nature and the erasure of past/present Black relational knowledges of land and its more-than-human inhabitants. This orientation is an articulation of our desires for Black childhood futurities outside of current carceral formations of schooling for many Black children in North America. At the same time, we also want to consider the ways in which these futurities might be situated within the everyday challenges and potentialities of relational livability amidst the ruins of an ecologically damaged anti-Black planet. 
A key orientation that we have found useful for our speculative storytelling is an ethos of radical relationality that disrupts colonialist hierarchical understandings of what it means to be human while also centering Black futurity. Black feminist scholar Chelsea Frazier, drawing from Octavia Butler, eloquently describes this potential of speculative fiction, as 'lead[ing] us away from the limitations of traditional environmental studies while offering transgressive visions that center Black subjectivity, challenge the (dis)connections between human and non-human entities, and initiate alternative notions of environmental/ecological ethics' (2016: 46). Our imaginaries of Black space in early childhood environmental education through speculative storytelling gestures towards educational places and spaces where Black childhoods are affirmed without a need for reliance on childhood innocence, which is always already racialized (Bernstein, 2017; Farley and Garlen, 2016). In these imaginaries, Black childhoods are not defined by the enclosures of anti-Blackness in schooling practices, and Black children's interests and curiosities about places and their more-than-human inhabitants are nurtured and taken seriously. As modes of testifying to and witnessing the survival of Black life amidst antiblackness and environmental precarity, the educator in our fictional story enacts affective pedagogies that affirm Black land knowledges while not ignoring the structural violences of pastpresent histories of both Indigenous and Black land dispossession (Nxumalo and ross, 2019).

The story in the paper is set in Oakland California in 2027, in a climate changed future that has severely decreased the livability of the planet and where Black people have escaped the antiBlackness of schooling and formed their own specialized schools. We tell the story of a school focused on learning with the environment, led by a teacher named Nyawela, where we tell of children's learning that is guided by ethos of telling situated science stories, affirming Black childhoods and foregrounding reciprocal relations; for example, children learn alongside Indigenous peoples about lessons from the Defenders of the Water School at Standing Rock about being in good relation with more-than-human others (Nxumalo and ross, 2019). We also note that the futures we story are far removed from the current realities of extreme regulation and surveillance of young Black children beginning in their earliest years of schooling in North American schooling contexts. However, we see this (re)storying work as a provocation to think of how imaginaries are necessary parts of refiguring Black life. As Benjamin powerfully states:

The facts, alone, will not save us ... we are drowning in "the facts" of inequality and injustice $\cdots$ In this context, novel fictions that reimagine and rework all that is taken for granted about the current structure of the social world -alternatives to capitalism, racism, and patriarchy-are urgently needed. Fictions, in this sense, are not falsehoods but refashionings through which analysts experiment with different scenarios, trajectories, and reversals, elaborating new values and testing different possibilities for creating more just and equitable societies. Such fictions are not meant to convince others of what is, but to expand our own visions of what is possible. (2016: 2) 
What new pedagogies might emerge from imaginaries that are aimed at disrupting anti-Black formations in environmental education?

\section{Disrupting settler colonialism in early childhood environmental education}

As mentioned earlier an important guiding orientation of my work is the necessity for environmental early childhood education that disrupts extractive, human-centered ways of learning about the more-than-human world. This disruption includes turning towards pedagogies that foreground radical relationality and reciprocity with the more-than-human beings, including, water, animals, plants, and land. I draw my understandings of radical relationality and its importance towards generating more livable worlds, from multiply situated Indigenous knowledges that foreground an intrinsic interconnection between humans and more-than-human relatives, and that recognize the agentic sociality of land, and waters; of all more-than-human life (Cajete, 2017; Mbiti, 1969; Recollet, 2016).

Importantly, brought to the context of early childhood education, an ethos of radical relationality unsettles the dominance of child-centered curriculum that is focused on the individual academic development of each child according to universalized norms. Instead the focus is on learning as relational; on what happens in-between children and more-than-human beings; where all of these beings are encountered as active participants in children's meaning-making rather than passive recipients of their 'nature' discoveries (Nxumalo, 2019a). In this orientation, children's relations within their local environment are seen as always inter-dependent including relations of environmental damage and vulnerability. An orientation towards radical relationality is also to signal that Western science while important, is inadequate to the immense task of teaching young people who have to grapple with the ethical and relational implications for living with human and morethan-human life in ecologically damaged environments (Marin and Bang, 2015; Nxumalo and Berg, 2020). Radical relationality can be thought of as a theory of change that is simultaneously an ethos and a pedagogical practice. This suggests then that ethical and political choices need to be made to work with the challenging task of trying out pedagogies that are intended to create movement towards children's subjectivities that enact relational, caring, and reciprocal ways of knowing and becoming -with place rather than those that reinforce human-centered and extractive relations.

An example of what such practices might look like are in a summer encounter for marginalized Latinx and Indigenous children and youth in San Marcos, Texas, led by Coahuiltecan elders that centers Coahuiltecan relations with land and water. My role has been to document the ways in which through song, art, dance, and ceremony, children learn how to be in good relation with land and 
water - including the Sacred Springs ${ }^{2}$ close to where the summer encounter is held which are central to the Coahuiltecan creation story. The children, elders and facilitators are in ceremony with water throughout the week beginning with the collaborative building of an altar containing water from the Sacred Springs and including an elder led water ceremony where each participant receives a vial filled with the Sacred Springs water. A multitude of intentional pedagogical provocations are engaged with throughout the week, including a lesson on the proposed Permian pipeline which threatens the aquifers that feed the springs. Through these pedagogical encounters, the young people are unsettling coloniality, engaging curriculum as ceremony, and enacting radical relationality that disrupts human-centric, extractive ways of relating to more than human worlds. While I do not necessarily see these pedagogies as steps to be followed, I think that early childhood educators in their own contexts, might consider how they might work with communities to enact and/or support sustaining land and water pedagogies. Such pedagogies then are an invitation to stay with the question of what kinds of education matter for young people growing up amidst the challenges of escalating, and unevenly distributed environmental precarity. The elders that lead this work are hopeful that such pedagogies might find their way to schools in San Marcos. Currently, they are developing a play based on the Sacred Springs creation story that they hope to bring to children and youth in San Marcos and beyond.

\section{Affective water pedagogies}

In turning towards the generative and interruptive potentials of affect for doing early childhood pedagogies differently, I draw inspiration from early childhood scholars who have shown how affect has potential as a mode of decentering human-centered modes of learning (Pacini-Ketchabaw, et al., 2016). Affect understood as inherently relational, brings forth possibilities that unsettle the focus on the individual developing child (Nxumalo, et al., 2018). Affective pedagogies include attunement to the multiple embodied ways in which children make sense of pedagogical encounters beyond normative discursive expressions of cognition. For instance, affective pedagogies can bring needed questions to early childhood education with regards to the (micro)politics of bringing attention to who and what gets to be affecting and affected and, the mattering of the 'where' of affect (Ahmed, 2014; Nxumalo and Villanueva, 2019). I have found taking seriously the 'where' of affect, to be generative in thinking with children's encounters with the more-than-human world in places and spaces of ecological damage where my intent has been to complicate romanticized narratives of children's relations with the natural world.

\footnotetext{
${ }^{2}$ The name Sacred Springs refers to the place that the Coahuiltecan elders I worked with call what is currently named San Marcos Springs at Spring Lake. This place is sacred to the Coahuiltecan people for many reasons, including as the site for their creation story.
} 
In considering what pedagogies of 'learning to be affected' by human and more-than-human relations (Pacini-Ketchabaw, et al., 2016) might look like; including how they might begin to undo colonial ways of learning about places, I have been engaged in an inquiry with children and educators on thinking with water. Over the course of 2.5 years, I have spent time with a group of kindergarten and preschool children and educators at a waste-filled creek that borders a suburban Austin independent school (Nxumalo and Villanueva, 2019, 2020a; Saint-Orens and Nxumalo, 2018). For the first year, I worked alongside Marleen, a member of the Miakan/Garza Coahuiltecan Band of Texas. Together, we spent time weekly at the creek with the educators and children on planned and emergent pedagogical encounters. An important part of how we engaged with the children with the creek and the surrounding area has been to slow down by sitting together at the creek bed to draw. Marleen and I have recently written about the drawings that emerged from children's affective responses to a Coahuiltecan water song that Marleen had taught the children that honours water and speaks to the importance of responsible, reciprocal and caring relations with Yana wana - the Coahuiltecan name for the waters of Central Texas that translates to 'spirit of the water'; speaking to water's agency and entanglement with humans (Nxumalo \& Villanueva, 2019, 2020a; Villanueva, 2018). Like the name Yana wana, the song presences this place as Indigenous land (Nxumalo, 2019c).

In our readings of the affective relationalities that emerged from the children's drawing and drawing processes, we consider the ways in which children's attachments of emotions of joy and happiness to the water materialize the spirit of the water and unsettle an anthropocentric reading of the children's drawings. We see the affective relationalities towards water as shaping and shaped by multiple material-discursive elements including the words spoken and sung in these moments, children's memories of the water stories we have been reading and sharing, the creek; the creekbed where we stand to sing, the discarded waste that is ever-present in the water despite our frequent efforts to 'clean up' ... and more. In further inquiring into the mattering of this moment we consider that

The art making is just one part of the affects, objects, human and more-than-human bodies, and discourses that come together to change how children act, feel and do. Within this assemblage art participates in changing what human and more-than-human bodies can do (Hickey-Moody, 2018) ... Just as the affective relationalities that emerge from these moments are more than what children say and do, the learning that happens in these inquiries also cannot be adequately captured by individual developmental descriptors of each individual child's art (Kind, 2010; Nxumalo and Rubin, 2018). Children's bodies, the pencils, crayons, the paper, the creek, the song - which children hum while they draw, and the other 'things, events, sounds, memories' are all active participants in this more-than-human place learning encounter. (Nxumalo and Villanueva, 2019: 48) 
I suggest here that these small everyday pedagogical encounters matter in generating what Haraway terms staying with the trouble; 'modest possibilities of partial recuperation and getting on together' (2016: 10). This mattering includes expanding capacities for child-land-water relatings that disrupt child-centered understandings of what nature can do for children or teach children. It also matters that these pedagogical encounters, while minor within the immense scale of ecological precarity, create openings for more-than-human relations that are affectively reparative while resisting the seduction of child-as-saviour discourses and their repetitions of Eurowestern developmentalism (Taylor, 2017). While we cannot know what will unfold in the future for the children, we are hopeful that in these minor moments, childhood subjectivities emerge that are more open to collective, place-attuned and reciprocal ways of being and becoming with land and water.

I am particularly interested in the ways in which thinking pedagogically with affect can include analyzing and responding to the ways in which power relations participate in determining 'who and what is affected, and who and what is deemed more easily as an "affectable other"' (Nxumalo and Villanueva, 2019: 48; Rowe and Tuck, 2017). This includes finding ways to articulate the ways in which place, settler colonialism, and anti-Blackness all matter in the affective pedagogies that I am trying out with the children and educators. In this regard, it is important to consider how the emergence of affect and its entanglement with socio-cultural and material-discursive forces, has consequences are not without tension (Ahmed, 2014; Rowe and Tuck, 2017). As Anne Stoler reminds me, affect is an important site at which colonialism and racialization manifest:

Colonial "common sense" [and] colonial racial epistemologies '.cannot be relegated to mere vestiges. They do not just benignly remain. In new force fields they are reactivated unevenly and strategically and are part of the fabric that shapes the liveliness of racialized ascriptions and the lividness of the affective states tied to them. (2011: 156)

In writing about our water inquiries with Marleen, we have noted the complexities of how our material, embodied and discursive subjectivities as Indigenous (Marleen) and Black (myself) people come to matter in relation to the lands in which our work is situated. For this particular work, this has meant that there are some water stories and practices that were intentionally not shared including some conversations and specific ceremonial practices and conversations that took place before and after the pedagogical encounters that remained between Marleen and myself. These practices are resonant with what Eve Tuck and K Wayne Yang (2014) describe as generative, ethical, intentional, and analytic practices of refusal that place boundaries around the forms of Indigenous and community knowledges that are made available for territorialization by the academy and those that are only for communities.

We have also grappled with how a pedagogical focus on decentering the universally developing child subject might simultaneously not cover-up that this is fraught work in working with 
mainly white settler children and educators on stolen, environmentally damaged Indigenous land amidst ongoing settler colonialism and anti-Blackness on Turtle Island (Nxumalo, 2019a). Put another way, the affective intensities that accompany this work are complex and contradictory - generating decolonial potentials while also making visible the differential vulnerabilities, privilege, and implicatedness that are embodied in our gatherings at the creek.

\section{Sensing sonic reverberations with Indigenous feminisms}

In further contemplating the pedagogical possibilities of our water pedagogies, Marleen and I have also written about how we see these pedagogies as enactments of an Indigenous feminist praxis that has decolonial resonances (Nxumalo and Villanueva, 2020b). For example, the water songs and spoken water stories have relational affective sonic reverberations that unsettle 'cartographies of dispossession' (Morrill, et al., 2016: 4) and the disappearing of Indigenous peoples and land. We find Cree scholar Karyn Recollet's (2015) work particularly helpful in our reading of the water pedagogies as activations of Indigenous relational knowledges that are simultaneously material, embodied, sonic and affective. Her work is particularly relevant to the context of our work with children and educators within the city of Austin. Recollet (2015) powerfully stories round dances that took place in the city of Toronto during an Indigenous mass movement called Idle No More. Recollet discusses the affects produced during these moments as having pedagogical and decolonial resonances. These affects emerge in connections between song, dancers' movements, and the (re)materializations and rethinking of urban space as Indigenous land (2015: 136). In connecting Recollet's Indigenous feminist insights on spatialized sonic decolonial affects we speculate that the collective affects that emerge in relations between children-creek waters-creekbed-trees-sky-critters-shaken rattlessinging-educators-Marleen-Fikile and more, activate decolonial 'geographies of resistance' (2015: 135). While again reiterating that we are seeking to unsettle individualist humanist views of our work, we argue that it matters that Marleen is present in this space as a member of a Coahuiltecan community who holds particular relations with Central Texas waters and embodies the Yana wana teachings she has learnt from her Coahuiltecan elders (Nxumalo and Villanueva, 2020b). I want to repeat here my contention that these minor place encounters matter for teaching and learning in ways that interrupt the colonialist humanist project of education in settler colonial contexts and create openings to more livable worlds. Importantly, these interruptions carefully foreground affective place relations in ways that do not disappear the ways in which different human subjects are differentially situated in and affected by the geographies of settler colonialism (Rowe and Tuck, 2017).

\section{Closing}

My collaborative engagements with affective pedagogies are for the most part shaped in relation with the particular geographies in which I work. At the same time connections across geographies 
are also important. For instance, in our work on water pedagogies with children in Central Texas, we also brought water stories from other places to children's learning - such as stories of Indigenous peoples working to protect water. I note this holding together of the specific and the general to underline that the questions raised in this work are relevant to other early childhood education contexts. For instance, early childhood educators and researchers in different contexts (many are already doing this), can inquire into what is opened up pedagogically, by paying close attention to affective dimensions of place encounters? For instance, what kinds of place-based pedagogical encounters are needed for young children and the general and specific precarities they are facing? As I write this in the midst of a pandemic and protests against anti-Black violence, it seems ever more urgent to rethink the purposes of early childhood education and how it can be more responsive to the ending of worlds as currently known and lived. What might it look like to teach and learn for 'the end of the modern-colonial habit-of-being' (Stein, 2019: 205)? One of several entry points to this enormous challenge includes inquiring into what kinds of affective pedagogies matter for young children in current times, and asking why affect matters for the increasingly precarious futures that young children are unevenly inheriting. What new kinds of pedagogical supports might be needed for early childhood educators to respond to the particular affective intensities that will continue to circulate with respect to anti-Blackness, climate, public health emergencies and their entanglements with structural inequity? That is to say, in particular educational contexts, what are some possibilities for attunement to affect as a response to both the separation of human and more-than-human life and the effects of human injustice? How might being on the lookout for affect also include a politics of responsibility towards unsettling taken for granted settler colonial and anti-Black effects that impact certain humans' capacities to act? How might affective childhood pedagogies also attend to the ways in which coloniality and anti-Blackness emerge within the realm of affect?

An additional important question is to ask how the pedagogical and conceptual orientations that I have discussed here might connect to higher education. Instead of answers, I will instead offer this is a closing invitation for those of us working in higher education to ask what situated, contextualized ethos and practices of radical relationality, of testifying/witnessing and affective decolonial pedagogies might bring to unsettling some of the ongoing colonial, anti-Black and extractivist conditions that continue to plague institutions of higher education in settler colonial places and spaces? That is to say, just as colonialism, anti-Blackness, and human centred extractivist relations with the earth are foundational to climate change, they are also foundational to higher education. Furthermore, higher education institutions continue to be implicated in these extractivist relations despite the currently popular rhetoric of sustainability; or what Sharon Stein describes as 'becom[ing] more sustainable while maintaining business as usual' (2019: 198 ) - where business as usual includes a lack of meaningful reckoning with the slave labour and stolen lands on which these institutions are built as well as the myriad overt and explicit ways in which institutions continue to marginalize Indigenous, Black and other intersectionally minoritized people. 
As one of many examples of the rhetoric of sustainability amidst ongoing colonial, extractivist business as usual - several educational institutions are participants in the TMT project which proposes to build a 30 meter telescope on Mauna Kea; a sacred mountain to Native Hawaiians. My dear colleague and Native Hawaiian scholar Dr. Uahikea Maile's work has powerfully made visible the workings of this project in imposing value to techno-science over Native Hawaiian peoples and land, including the ways in which 'the signification of scientific progress camouflages capitalism's racist, and also colonial, developmentalism: develop through time by developing space' (2019: 62).

Returning to my earlier words then; an orientation towards radical relationality is an important reminder that Western science alone is inadequate to the necessary task of disrupting colonial separation of human and more than human life on stolen Indigenous lands. So perhaps again this could be seen as an invitation for higher education, at multiple levels, to engage with the question of what radical relationality, testifying/witnessing and orientations towards learning to be affected by our more-than-human relations can look like and what these attunements might help to unsettle in higher education when situated within ongoing and escalating unlivability.

\section{Acknowledgements}

The Austin research described in this paper was supported by a grant from the University of Texas at Austin's Planet Texas 2050 Grand Challenge research initiative.

\section{Author Biography}

Dr. Fikile Nxumalo is an assistant professor of Early Childhood Education at the Ontario Institute for Studies in Education, University of Toronto. Her research examines geographies of childhood, antiblackness, and settler colonialism in early learning contexts.

\section{References}

Ahmed, S. 2014. The Cultural Politics of Emotion. 2nd Edition. Edinburgh: Edinburgh Univ. Press.

Barad, K. 2007. Meeting the Universe Halfway: Quantum Physics and the Entanglement of Matter and Meaning. Durham: Duke University Press.

Benjamin, R. 2016. Racial fictions, biological facts: Expanding the sociological imagination through speculative methods. Catalyst: Feminism, Theory, Technoscience, 2(2): 1-28.

Bernstein, R. 2011. Racial Innocence: Performing American Childhood and Race from Slavery to Civil Rights. New York: New York University Press.

Butler, O. 1995. Parable of the Sower. New York: Time Warner Books.

Butler, O. E. 1998. Parable of the Talents. New York: Grand Central Publishing.

Cairns, K. 2017. Connecting to Food: Cultivating Children in the School Garden. Children's Geographies, 15(3): 304-318. 
Cajete, G. 2017. Children, myth and storytelling: An Indigenous perspective. Global Studies of Childhood, 7(2): 113-130.

Chilisa, B. 2019. Indigenous Research Methodologies. 2nd Edition. London: SAGE Publishing.

Chilisa, B., Major, T. E. \& Khudu-Petersen, K. 2017. Community engagement with a postcolonial, African-based relational paradigm. Qualitative Research, 17(3): 326-339.

Collins, P. H. 2008. Black Feminist Thought: Knowledge, Consciousness, and the Politics of empowerment. 3rd Edition. London: Routledge.

Collins, P. H. 1989. The social construction of Black feminist thought. Signs: Journal of Women in Culture and Society, 14(4): 745-773.

Collins, P. H. 1998. Fighting Words: Black Women and the Search for Justice. Minnesota: University of Minnesota Press.

Davis, H., \& Todd, Z. 2017. On the importance of a date, or, decolonizing the Anthropocene. ACME: An International Journal for Critical Geographies, 16(4): 761-780.

Nxumalo, F., Vintimilla C. D. \& Nelson, N. 2018. Pedagogical gatherings in early childhood education: Mapping interferences in emergent curriculum. Curriculum Inquiry, 48(4): 433-453.

Dumas, M. J. \& ross, k. m. 2016. 'Be real Black for me': Imagining BlackCrit in education. Urban Education, 51(4): 415-442.

Farley, L. \& Garlen, J. C. 2016. The child in question: Childhood texts, cultures, and curricula. Curriculum Inquiry, 46(3): 221-229.

Frazier, C. M. 2016. Troubling ecology: Wangechi Mutu, Octavia Butler, and Black feminist interventions in environmentalism. Critical Ethnic Studies, 2(1): 40-72.

Haraway, D. J. 2016. Staying with the Trouble: Making Kin in the Chthulucene. Durham: Duke University Press.

Haraway, D. 2003. Situated knowledges: The science question in feminism and the privilege of partial perspective. In Y.S. Lincoln \& N.K. Denzin (eds.) Turning Points in Qualitative Research: Tying Knots in a Handkerchief. Lanham: Altamira Press, 21-46.

Hartman, S. V. 2007. Lose your Mother: A Journey along the Atlantic Slave Route. New York: Farrar, Straus and Giroux.

Hickey-Moody, A. 2018. Materialising the social. Ruukuu: Studies in Artistic Research, 9. Available at: https://www.researchcatalogue.net/view/371583/371584 (accessed 12 March 2020).

Jackson, Z. I. 2015. Outer worlds: The persistence of race in movement 'Beyond the Human'. GLQ: $A$ Journal of Lesbian and Gay Studies, 21(2/3): 215-218.

Kind, S. 2010. Art encounters: Movements in the visual arts and early childhood education. In V. Pacini-Ketchabaw (ed.) Flows, Rhythms and Intensities of Early Childhood Education Curriculum. New York, NY: Peter Lang, 113-132.

King, T. L. 2019. The Black Shoals: Offshore Formations of Black and Native Studies. Durham: Duke University Press. 
King, T. L. 2017. Humans involved: Lurking in the lines of posthumanist flight. Critical Ethnic Studies, 3(1): 162-185.

Maile, D. M. 2019. Resurgent refusals: Protecting Mauna a Wākea and Kanaka Maoli decolonization. Hülili: Multidisciplinary Research on Hawailan Well-Being, 11(1): 57-69.

Marin, A. \& Bang, M. 2015. Repatriating science teaching and learning: Finding our way to storywork. Journal of American Indian Education, 54(2): 29-51.

Mbiti, J. S. 1969. Introduction to African religion. London: Heinemann.

McKittrick, K. 2013. Plantation futures. Small Axe: A Caribbean Platform for Criticism, 17(3): 1-15.

Morrill, A., Tuck, E. \& The Super Futures Haunt Collective. 2016. Before dispossession, or surviving it. Liminalities: A Journal of Performance Studies, 12: 1-20.

Nelson, N., Pacini-Ketchabaw, V. \& Nxumalo, F. 2018. Rethinking nature-based approaches in early childhood: Common worlding practices. Journal of Childhood Studies, 43(1): 4-14.

Nxumalo, F. 2018. Situating Indigenous and Black childhoods in the Anthropocene. In CutterMackenzie, A., Malone, K. \& Barratt Hacking, E. (eds.) International research handbook on childhoodnature: Assemblages of childhood and nature research, London: Springer, 1-22. DOI: https://doi.org/10.1007/978-3-319-51949-4_37-2

Nxumalo, F. 2019a. Decolonizing Place in Early Childhood Education. London: Routledge.

Nxumalo, F. 2019b. Disrupting racial capitalist formations in early childhood education. In Nxumalo, F. \& Brown, C. P. (eds.) Disrupting and Countering Deficits in Early Childhood Education =. London: Routledge Education, 164-178.

Nxumalo, F. 2019c. Presencing: Decolonial attunements to children's place relations. In. Hodgins, D. (ed.) Feminist Research for 21st-Century Childhoods: Common Worlds Methods. London: Bloomsbury Publishers, 159-168.

Nxumalo, F. \& Berg, L. 2020. Conversations on climate change pedagogies in a Central Texas kindergarten classroom. In Henderson, J.A. \& Drewes, A. (eds.) Teaching Climate Change in the United States. London: Routledge.

Nxumalo, F. \& Cedillo, S. 2017. Decolonizing 'place' in early childhood studies: Thinking with Indigenous onto-epistemologies and Black feminist geographies. Global Studies of Childhood, 7(2): 99-112.

Nxumalo, F. \& ross, k.m. 2019. Envisioning Black space in environmental education for young children. Race, Ethnicity \& Education, 22(4): 502-524.

Nxumalo, F. \& Rubin, J. C. 2018. Encountering waste landscapes: More-than-human place literacies in early childhood education. In Kuby, C.R., Spector, K. \& Johnson Thiel, J. (eds.) Posthumanism and Literacy Education: Knowing/being/doing Literacies). London: Routledge, 201-213.

Nxumalo, F. \& Villanueva, M. 2019. Decolonial water stories: affective pedagogies with young children. International Journal of Early Childhood Environmental Education, 7(1): 40-56. 
Nxumalo, F. \& Villanueva, M. (2020a). (Re)storying Water: Decolonial pedagogies of relational affect with young children. In Dernikos, B., Lesko, N., McCall, S. D. \& Niccolini, A. (eds.) Mapping the Affective Turn in Education: Theory, Research, and Pedagogy. London: Routledge, 209-228.

Nxumalo, F. \& Villanueva, M. (2020b). Listening to water: Situated dialogues between Black, Indigenous \& Black-Indigenous feminisms. In Taylor, C., Ulmer, J. \& Hughes, C. (eds.) Transdisciplinary feminist Research Practices: Innovations in Theory, Method and Practice. New York: Routledge, 59-75.

Pacini-Ketchabaw, V., Taylor, A. \& Blaise, M. 2016. Decentring the human in multispecies ethnographies. In Taylor, C. \& Hughes, C. (eds.) Posthuman research practices in education. London: Palgrave Macmillan, 149-167.

Pérez, M. S. \& Saavedra, C. M. 2017. A call for onto-epistemological diversity in early childhood education and care: Centering global south conceptualizations of childhood. Review of Research in Education, 41: 1-29.

Recollet, K. 2015. Glyphing decolonial love through urban flash mobbing and Walking with our Sisters. Curriculum Inquiry, 45(1): 129-145.

Recollet, K. 2016. Gesturing Indigenous futurities through the remix. Dance Research Journal, 48(1): 91-105.

Rowe, A. C. \& Tuck, E. 2017. Settler colonialism and cultural studies: Ongoing settlement, cultural production, and resistance. Cultural Studies $\leftrightarrow$ Critical Methodologies, 17: 3-13.

Saint-Orens, L. \& Nxumalo, F. 2018. Engaging with living waters: An inquiry into children's relations with a local Austin creek. Journal of Childhood Studies, 43(1): 68-72.

Sharpe, C. 2016. In the Wake: On Blackness and Being. Durham: Duke University Press.

Simpson, L. B. 2014. Land as pedagogy: Nishnaabeg intelligence and rebellious transformation. Decolonization: Indigeneity, Education \& Society, 3(3): 1-25.

Stein, S. 2019. The ethical and ecological limits of sustainability: A decolonial approach to climate change in higher education. Australian Journal of Environmental Education, 35: 198-212.

Stoler, A. L. 2011. Colonial aphasia: Race and disabled histories in France. Public Culture, 23(1): 121 156.

Tarpley, N. (ed.) 1995. Testimony: Young African-Americans on Self-Discovery and Black Identity. Boston: Beacon Press.

Taylor, A. 2017. Beyond Stewardship: Common world pedagogies for the Anthropocene. Environmental Education Research, 23(10): 1448-1461.

Todd, Z. 2016. An Indigenous feminist's take on the ontological turn: 'Ontology' is just another word for colonialism. Journal of Historical Sociology, 29: 4-22.

Tuck, E. 2014. A turn to where we already were? Settler inquiry, indigenous philosophy, and the ontological turn. Paper presented to the Annual Meeting of the American Educational Research Association, Philadelphia, PA. April 2014. 
Tuck, E., Guess, A. \& Sultan, H. 2014. Not nowhere: Collaborating on selfsame land. Decolonization: Indigeneity, Education \& Society blog. Available at: https://decolonization.files.wordpress.com/2014/06/notnowhere-pdf.pdf_(accessed 12 March 2020).

Tuck, E., McKenzie, M. \& McCoy, K. 2014. Land education: Indigenous, post-colonial, and decolonizing perspectives on place and environmental education research. Environmental Education Research, 20(1): 1-23.

Tuck, E. \& Yang, K. W. 2014. Unbecoming claims: Pedagogies of refusal in qualitative research. Qualitative Inquiry, 20(6): 811-818.

Vergès, F. 2017. Racial capitalocene. In Johnson, C.T. \& Lubin, A. (eds.) Futures of Black Radicalism. London: Verso Books, 72-82.

Villanueva, M. 2018. An Auto-Ethnography of Water as Life: Decolonizing our Connection with Mother Earth. Unpublished MA Thesis, University of Texas, Austin.

Vintimilla, C. D. 2016. Educators and pedagogista: Encounters at the intersection of history and story. Contemporary Issues in Early Childhood Education, 19(1): 20-30. 